\title{
The first molecular identification of benzimidazole resistance in Haemonchus contortus from goats in Thailand
}

\author{
Opal Pitaksakulrat ${ }^{1,2}\left(\mathbb{D}\right.$, Monticha Chaiyasaeng ${ }^{1,2} \mathbb{D}$, Atchara Artchayasawat ${ }^{1,2} \mathbb{D}$, Chatanun Eamudomkarn ${ }^{1,2}$ (D),
} Sorawat Thongsahuan ${ }^{3}$ (i) and Thidarut Boonmars ${ }^{1,2,4}$

\begin{abstract}
1. Department of Parasitology, Faculty of Medicine, Khon Kaen University, Khon Kaen 40002, Thailand; 2. Liver Fluke and Cholangiocarcinoma Research Institute, Faculty of Medicine, Khon Kaen University, Khon Kaen 40002, Thailand;

3. Faculty of Veterinary Science, Prince of Songkla University, Songkhla 90110, Thailand; 4. Neglected, Zoonosis and Vector-Borne Disease Research Group, Khon Kaen University, Khon Kaen 40002, Thailand.

Corresponding author: Thidarut Boonmars, e-mail: bthida@kku.ac.th

Co-authors: OP: opalpi@kku.ac.th, MC: monticha.care@gmail.com, AA: atchara_a@kkumail.com, CE: chatea@kku.ac.th, ST: sorawat.t@psu.ac.th

Received: 23-09-2020, Accepted: 05-02-2021, Published online: 25-03-2021
\end{abstract}

doi: www.doi.org/10.14202/vetworld.2021.764-768 How to cite this article: Pitaksakulrat O, Chaiyasaeng M, Artchayasawat A, Eamudomkarn C, Thongsahuan S, Boonmars T (2021) The first molecular identification of benzimidazole resistance in Haemonchus contortus from goats in Thailand, Veterinary World, 14(3): 764-768.

\begin{abstract}
Background and Aim: Haemonchus contortus is one of the major trichostrongyloid nematodes affecting small ruminant production worldwide, especially in tropical and subtropical regions. Adult H. contortus suck the blood from the host abomasum leading to anemia and often death in heavily infected animals. The mainstay of parasitic control is an anthelmintic drug, but long-term drug use may cause drug resistance. The aim of this study was to examine benzimidazole resistance in $H$. contortus of goats from different regions in Thailand by detecting the frequency of the F200Y polymorphism in the $\beta$-tubulin isotype 1 gene.
\end{abstract}

Materials and Methods: A total of $121 \mathrm{H}$. contortus adults were obtained from 31 naturally infected out of 37 slaughtered goats from city abattoirs in five regions of Thailand. The frequency of the F200Y polymorphism in the $\beta$-tubulin isotype 1 gene was detected following the allele-specific polymerase chain reaction protocol.

Results: The overall genotype frequencies in Thailand were homozygous resistant (RR: 24\%), heterozygous (SR: 44.6\%), and homozygous susceptible (SS: 31.4\%). The allele frequencies were resistant allele (R: 46\%) and susceptible allele (S: $54 \%$ ). The R allele frequency and the RR genotype varied from $30 \%$ to $65 \%$ and $0 \%$ to $43.9 \%$, respectively. The frequency of $\mathrm{R}$ alleles was significantly higher in the southern region $(0.65)$ as compared to northern $(0.30, \mathrm{p}=0.001)$, western $(0.38$, $\mathrm{p}=0.04)$, and central regions $(0.30, \mathrm{p}=0.03)$. The $\mathrm{RR}$ genotype was also significantly higher in the southern region $(43.9 \%)$ versus the northern $(0 \%, \mathrm{p}=0.001)$, western $(11.8 \%, \mathrm{p}=0.012)$, and central regions $(17.4 \%, \mathrm{p}=0.001)$.

Conclusion: This is the first study of the detection of single-nucleotide polymorphisms in codon 200 of the $\beta$-tubulin isotype 1 gene of $H$. contortus from goats in Thailand. These findings are essential and imply that an integrated approach is needed for issues such as drug treatment, farm management, prevention, and control strategies. This is of interest to farmers, veterinarians, and the department of livestock.

Keywords: benzimidazole resistance, Haemonchus contortus, single-nucleotide polymorphism in codon $200 \beta$-tubulin isotype 1 gene.

\section{Introduction}

The livestock industry plays an important role in the agricultural economy. It has an average global growth rate of $40 \%$ of gross agricultural production in developing countries. They contribute to food security and nutrition, livelihoods, as well as national economic development. In Thailand, small ruminants such as goats are very popular because they are easy to manage and are in demand [1]. Haemonchus contortus is a trichostrongyloid nematode and an important parasitic disease that poses significant economic

Copyright: Pitaksakulrat, et al. Open Access. This article is distributed under the terms of the Creative Commons Attribution 4.0 International License (http://creativecommons.org/licenses/ by/4.0/), which permits unrestricted use, distribution, and reproduction in any medium, provided you give appropriate credit to the original author(s) and the source, provide a link to the Creative Commons license, and indicate if changes were made. The Creative Commons Public Domain Dedication waiver (http:// creativecommons.org/publicdomain/zero/1.0/) applies to the data made available in this article, unless otherwise stated. losses in small ruminants [2,3]. Small ruminants are infested with the worm when they graze with the infecting larvae (L3). After a host has ingested L3 larvae, the worm will burrow into the abomasum (true stomach) where it develops into an adult stage. Adult male and female worms live in the abomasum of the ruminants where they feed on blood. The adults feed on blood from host abomasa resulting in anemia and stunted growth, which can lead to edema until death in heavily infected animals [4]. Several studies have reported this parasite in Thailand [5-7]. Moreover, in terms of zoonotic parasite, many studies have also reported that $H$. contortus can infect humans [8-10] and this supports the One Health approach concern.

The control of hemonchosis is mostly based on anthelmintic treatment (ATH), including benzimidazole, but this may increase the emergence of anthelmintic resistance. Many countries such as Brazil, China, India, Pakistan, and the United States 
of America have reported anthelmintic resistance of this parasite to all major classes of ATH drugs [11-21]. Benzimidazole (BZ) resistance has been associated with three different mutations in the $\beta$-tubulin isotype 1 gene in $H$. contortus with single-nucleotide polymorphism (SNPs). These mutations include the replacement of a phenylalanine (Phe, TTC) by a tyrosine (Tyr, TAC) at positions 200 [22] and 167 [23] and rare SNPs that alters Ala (GCA) to Glu (GAA) at position 198 of $\beta$-tubulin isotype 1 gene [24].

Thus, the aim of this study was to examine benzimidazole resistance in $H$. contortus of goats from different regions in Thailand by detecting the frequency of the F200Y polymorphism in the $\beta$-tubulin isotype 1 gene. The data generated from this study are essential for understanding the status of $\mathrm{BZ}$ resistance and may integrate approaches for farm management and ATH program, thus reducing the economic losses from anthelmintic resistance in Thailand.

\section{Materials and Methods}

\section{Ethical approval}

No ethical approval required for this study because $H$. contortus samples were collected from slaughtered animals.

\section{Study period, area, and sampling}

This study was conducted from January 2019 to February 2020. H. contortus worms were recovered from 31 naturally infected out of 37 small ruminant abomasa from city abattoirs from eight provinces in five different regions of Thailand (the north, west, central, northeast, and south; Table-1 and Figure-1). Each abomasum was opened, and the contents were washed into a glass beaker. The worms were morphologically identified at the genus level Haemonchus spp. [25]. Male and female Haemonchus were identified at the species level under a microscope [2,26]. All worms were thoroughly washed in $0.85 \%$ physiological saline and then stored at $-20^{\circ} \mathrm{C}$ until used for molecular analysis.

Table-1: Haemonchus contortus adult worms were collected from goats in eight city abattoirs from five different regions of Thailand.

\begin{tabular}{|c|c|c|c|}
\hline Regions & Province/code & $\begin{array}{c}\text { No. of } \\
\text { abomasum }\end{array}$ & $\begin{array}{c}\text { Geographical } \\
\text { localities }\end{array}$ \\
\hline North & Chiang Mai/N1 & 3 & $\begin{array}{l}18^{\circ} 46^{\prime} 40.7^{\prime \prime} \mathrm{N} \\
98^{\circ} 59^{\prime} 52.8^{\prime \prime} \mathrm{E}\end{array}$ \\
\hline West & Tak/W1 & 5 & $\begin{array}{l}16^{\circ} 45^{\prime} 03.8^{\prime \prime} \mathrm{N} \\
98^{\circ} 30^{\prime} 36.5^{\prime \prime} \mathrm{E}\end{array}$ \\
\hline Northeast & $\begin{array}{l}\text { Nakhon } \\
\text { Ratchasima/NE1 }\end{array}$ & 8 & $\begin{array}{c}14^{\circ} 59^{\prime} 10.7^{\prime \prime} \mathrm{N} \\
102^{\circ} 06^{\prime} 19.1^{\prime \prime} \mathrm{E}\end{array}$ \\
\hline \multirow[t]{2}{*}{ Central } & Lopburi/C1 & 6 & $\begin{array}{c}14^{\circ} 47^{\prime} 43.5^{\prime \prime} \mathrm{N} \\
100^{\circ} 40^{\prime} 14.2^{\prime \prime} \mathrm{E}\end{array}$ \\
\hline & Nakhon Sawan/C2 & 1 & $\begin{array}{c}15^{\circ} 43^{\prime} 06.1^{\prime \prime} \mathrm{N} \\
100^{\circ} 06^{\prime} 52.8^{\prime \prime} \mathrm{E}\end{array}$ \\
\hline \multirow[t]{3}{*}{ South } & Surat Thani/S1 & 1 & $\begin{array}{c}8^{\circ} 38^{\prime} 28.4^{\prime \prime} \mathrm{N} \\
99^{\circ} 20^{\prime} 02.5^{\prime \prime} \mathrm{E}\end{array}$ \\
\hline & $\begin{array}{l}\text { Nakhon } \mathrm{Si} \\
\text { Thammarat/S2 }\end{array}$ & 3 & $\begin{array}{l}8^{\circ} 38^{\prime} 39.6^{\prime \prime} \mathrm{N} \\
99^{\circ} 56^{\prime} 45.6^{\prime \prime} \mathrm{E}\end{array}$ \\
\hline & Krabi/S3 & 4 & $\begin{array}{l}7^{\circ} 38^{\prime} 10.5^{\prime \prime} \mathrm{N} \\
99^{\circ} 06^{\prime} 40.8^{\prime \prime} \mathrm{E}\end{array}$ \\
\hline Total & 8 & 31 & \\
\hline
\end{tabular}

\section{Isolation of genomic DNA}

Male and female worms from each abomasum were pooled for each population of $H$. contortus from eight provinces in the five regions. The male and female adults of $H$. contortus were randomly selected from the pooled sample of each of the eight populations for detecting the BZ resistance analysis. The genomic DNA was extracted from 121 individual male and female worms from eight populations using the DNeasy blood and tissue kit (QIAGEN Ltd., Crawley, West Sussex, UK). The DNA was eluted in a total volume of $25 \mu \mathrm{L}$. The concentration and quality of the extracted DNA were then measured in a Nanodrop spectrophotometer.

\section{Allele-specific polymerase chain reaction (AS-PCR)} amplification

To examine the frequency of the F200Y polymorphism in the $\beta$-tubulin isotype 1 gene, the resistant (R) and susceptible (S) alleles were explored following the AS-PCR protocol [27]. The AS-PCR was amplified in single reaction using the four primers as follows: Non-AS PH1 (5'-GGA ACG ATG GGA CTC CTT TCG-3'), susceptible AS PH4 (5'-ATA CAG AGC TTC GTT GTC AAT ACA AG-3'), resistant AS PH3 (5'-CTG GTA GAG AAC ACC GAT GAA ACA-3'), and non-AS Pn2 (5'-GAT CAG CAT TCA GCT GTC CA-3'). The

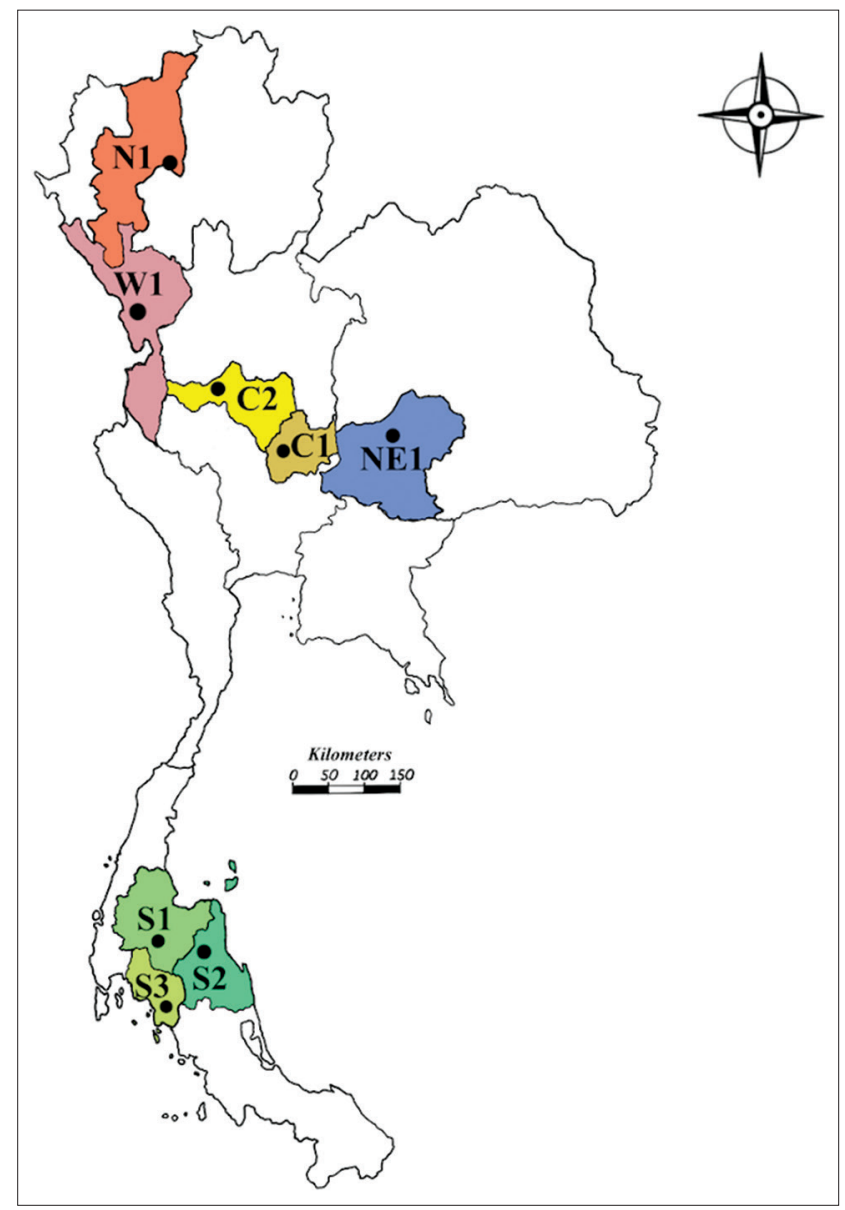

Figure-1: Haemonchus contortus adult worms were collected from goats in eight city abattoirs from five different regions of Thailand (Thailand map was modified from https://go.gistda.or.th). 
PCR mixture has a total volume of $25 \mu \mathrm{L}$ using illustra $^{\mathrm{TM}}$ pureTaq Ready-To-Go PCR Beads (GE Healthcare, UK), 10 pmol of each primer, and $2.0 \mu \mathrm{L}$ of DNA template (50-100 $\mathrm{ng} / \mu \mathrm{L})$. The following PCR conditions were used: Initial denaturation at $94^{\circ} \mathrm{C}$ for $15 \mathrm{~min}, 40$ cycles of denaturation at $95^{\circ} \mathrm{C}$ for $1 \mathrm{~min}$, annealing at $60^{\circ} \mathrm{C}$ for $1 \mathrm{~min}$, and extension at $72^{\circ} \mathrm{C}$ for $1 \mathrm{~min}$; the final elongation step was at $72^{\circ} \mathrm{C}$ for $10 \mathrm{~min}$. After AS-PCR amplification, allele-specific analysis used electrophoresis in $2 \%$ agarose gel stained with ethidium bromide. The susceptible, resistant, and non-specific bands were observed at approximately 550, 250, and $650 \mathrm{bp}$, respectively. The genotypes of adults were homozygous resistant (RR), homozygous susceptible (SS), and heterozygous (SR).

\section{Statistical analysis}

A Chi-square test compared the allele and genotype frequencies of adult $H$. contortus from five different regions [28].

\section{Results}

There were 121 male and female H. contortus adults from eight populations in five regions - these were genotyped to detect SNPs in codon 200 of the $\beta$-tubulin isotype 1 gene. The allele and genotype frequencies are given in Table-2 and Figure-2. Three genotypes (RR, SR, and SS) were detected. The overall genotype frequencies of $H$. contortus adults in Thailand were homozygous resistant (RR: 24\%), heterozygous (SR: $44.6 \%$ ), and homozygous susceptible (SS: 31.4\%). The allele frequencies were resistant allele (R: $46 \%$ ) and susceptible allele (S: 54\%).

The homozygous resistant (RR) had high frequencies $(25-43.9 \%)$ in the northeast and southern regions. They were low (0-17.4\%) in three others (north, west, and central regions). The genotype that was heterozygous (SR) and homozygous susceptible (SS) was detected in all regions ranging from $26.1 \%$ to $52.9 \%$ and $14.6 \%$ to $56.5 \%$, respectively. The resistance genotype (RR) was also significantly higher in the southern region $(43.9 \%)$ versus the northern $(0 \%, \mathrm{p}=0.001)$, western $(11.8 \%$, $\mathrm{p}=0.012)$, and central regions $(17.4 \%, \mathrm{p}=0.001)$.
The resistance alleles frequency associated with $\mathrm{BZ}$ in $H$. contortus from eight provinces in five regions varied from $30 \%$ to $65 \%$ and the susceptible alleles frequency ranged from $35 \%$ to $70 \%$. The highest resistant alleles (R) frequency $(65 \%)$ was in the south. The frequency of the $\mathrm{R}$ alleles was significantly higher in the southern region $(0.65)$ versus the northern $(0.30, p=0.001)$, western $(0.38, p=0.04)$, and central regions $(0.3, \mathrm{p}=0.03)$.

\section{Discussion}

This is the first evidence of BZ resistance from $H$. contortus in Thailand by screening the frequency of the F200Y polymorphism in the $\beta$-tubulin isotype 1 gene. The objective of this study was to examine SNPs in codon 200 of $H$. contortus adults from different regions in Thailand using the AS-PCR technique. This technique used four primers in a single reaction to save time and reagent costs. Moreover, this technique is easy and rapid to determine the $\mathrm{BZ}$ resistance in $H$. contortus. We detected a high frequency of resistant homozygous $\mathrm{RR}$ in the southern region (65\%) similar to the previous studies in China (31\%), Egypt (69.44\%), Northwest India (74\%), North India (53-85\%), Hungary $(87.2 \%)$, Brazil (66.7-93.97\%), India (98\%), and East Amazon $(100 \%)$ [14,29-35]. The low frequencies of resistance allele (0-15\%) in H. contortus in three others (the northern, western, and the central regions) are similar to a study in Brazil (5\%) [36]. This may be because of lower use of ATH drug by farmers and low pasture contamination with the other ruminants $[1,33]$.

In Thailand, the treatment of hemonchosis mostly uses two groups of broad-spectrum anthelmintic drugs, including benzimidazole and avermectins. Thai veterinarians and farmers often use BZ such as albendazole, for an extended period of time. The long-term administration of the same drug (albendazole) could change the relative allele frequency of $\beta$-tubulin isotype 1 genes associated with BZ resistance in this parasite $[1,31,33]$.

In the south, the frequency of resistance alleles (R) and genotypes (RR) was higher than other regions,

Table-2: Genotype and allele frequencies associated with BZ in Haemonchus contortus adult from goats in eight provinces of five regions, Thailand.

\begin{tabular}{|c|c|c|c|c|c|c|c|}
\hline \multirow[t]{2}{*}{ Regions } & \multirow[t]{2}{*}{ Province } & \multirow{2}{*}{$\begin{array}{l}\text { Number of worm } \\
\text { in each pool }\end{array}$} & \multicolumn{3}{|c|}{ Genotype frequency (\%) } & \multicolumn{2}{|c|}{ Allele frequency } \\
\hline & & & $\mathbf{R} \mathbf{R}$ & SR & SS & Resistant (R) & Susceptible (S) \\
\hline North & Chiang Mai & 20 & 0 & $12(60.0)$ & $8(40.0)$ & $0.30 *$ & $0.70 *$ \\
\hline West & Tak & 17 & $2(11.8) *$ & $9(52.9)$ & $6(35.3) *$ & $0.38 *$ & $0.62 *$ \\
\hline Northeast & Nakhon Ratchasima & 20 & $5(25.0)$ & $10(50.0)$ & $5(25.0)$ & 0.50 & 0.50 \\
\hline \multirow[t]{3}{*}{ Central } & Lopburi & 20 & $3(15.0)^{*}$ & $6(30.0)$ & $11(55.0) *$ & 0.30 & 0.70 \\
\hline & Nakhon Sawan & 3 & $1(33.3)$ & 0 & $2(66.7)$ & 0.30 & 0.70 \\
\hline & Total & 23 & $4(17.4)^{*}$ & $6(26.1)$ & $13(56.5) *$ & $0.30 *$ & $0.70 *$ \\
\hline \multirow[t]{4}{*}{ South } & Surat Thani & 9 & $8(88.9)$ & $1(11.1)$ & 0 & 0.94 & 0.06 \\
\hline & $\begin{array}{l}\text { Nakhon Si } \\
\text { Thammarat }\end{array}$ & 15 & $5(33.3)$ & $7(46.7)$ & $3(20.0)$ & 0.57 & 0.43 \\
\hline & Krabi & 17 & $5(29.4)$ & $9(53.0)$ & $3(17.6)$ & 0.56 & 0.44 \\
\hline & Total & 41 & $18(43.9) *$ & $17(41.5)$ & $6(14.6)^{*}$ & $0.65^{*}$ & $0.35^{*}$ \\
\hline Total & & 121 & $29(24.0)$ & $54(44.6)$ & $38(31.4)$ & 0.46 & 0.54 \\
\hline
\end{tabular}

*Indicates significance at $\mathrm{P}<0.05$

Veterinary World, EISSN: 2231-0916 


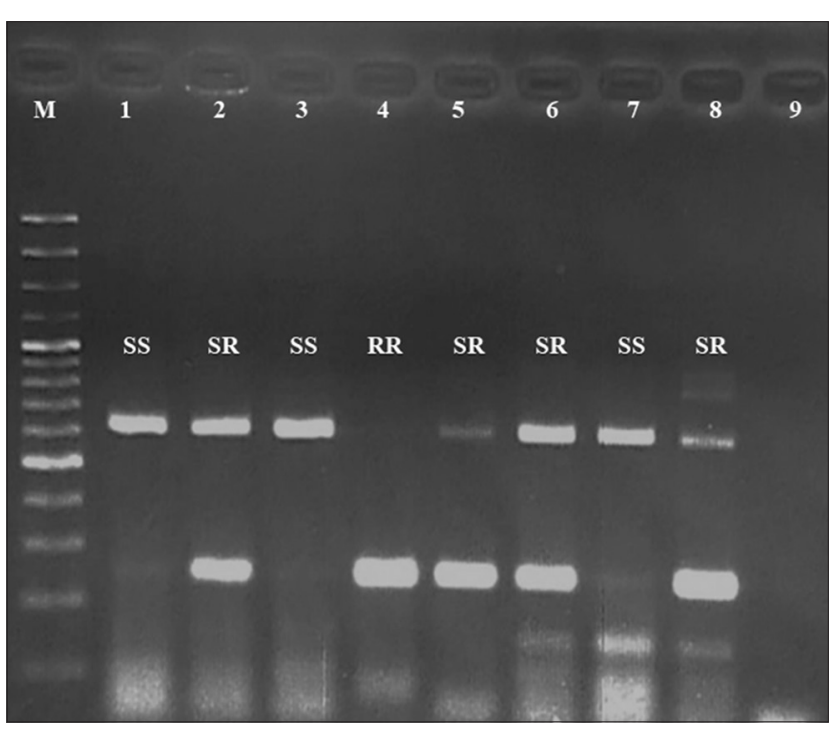

Figure-2: Polymerase chain reaction product of $\beta$-tubulin gene from Haemonchus contortus, lane $M$ is DNA ladder (100 bp), lane $1-8$ is PCR product of $\beta$-tubulin gene, lane 9 is negative control. The genotype; homozygous resistant (RR), homozygous susceptible (SS), and heterozygous (SR).

perhaps because of frequent dosing, under dosing of BZ drug, and high pasture contamination with the other ruminants such as cattle in the same area. Moreover, small ruminant agriculture, including goats is mainly located in the south because this animal is popular and important for Muslim people (goats are associated with the Muslim religion and culture) [1]. Goats have been raised for generations so the worm may be in contact with ATH drug for a long time leading to resistance $[31,33]$. These results confirm the rapid emergence and selection of allele resistance in South Thailand.

\section{Conclusion}

This is the first molecular identification of BZ resistance (SNPs in codon 200 of the $\beta$-tubulin isotype 1 gene in $H$. contortus) from goats in Thailand. Our results showed that three genotypes (RR, SR, and SS) were detected in five regions. The high resistance allele frequency and the resistance genotype in codon 200 of the $\beta$-tubulin isotype 1 gene of $H$. contortus from goats were observed in South Thailand. These data are essential for understanding BZ resistance in Thailand and may integrate approaches for farmers, veterinarians, and the government. Farm management could include ATH drug treatment or grassland rotation plans to reduce the economic losses from anthelmintic resistance.

\section{Authors' Contributions}

OP, MC, AA, ST, and TB: Data curation, investigation, methodology, and formal analysis. OP and TB: Conceptualization and project administration. TB: Supervision and visualization. OP, AA, CE, and TB: Drafted and revised the manuscript. All authors read and approved the final manuscript.

\section{Acknowledgments}

This research was supported by the Office of the Higher Education and the Thailand Research Fund (grant number MRG6180091); and the Young Researcher Development Project of Khon Kaen University, Thailand.

\section{Competing Interests}

The authors declare that they have no competing interests.

\section{Publisher's Note}

Veterinary World remains neutral with regard to jurisdictional claims in published map and institutional affiliation.

\section{References}

1. DLD. (2017) Yearly Statistics Report 2016 - Department of Livestock Development, Ministry of Agricultural and Cooperatives, Bangkok, Thailand.

2. Achi, Y.L., Zinsstag, J., Yao, K., Yeo, N., Dorchies, P. and Jacquiet, P. (2003) Host specificity of Haemonchus spp. for domestic ruminants in the savanna in northern Ivory Coast. Vet. Parasitol., 116(2): 151-158.

3. O'Connor, L.J., Walkden-Brown, S.W. and Kahn, L.P. (2006) Ecology of the free-living stages of major trichostrongylid parasites of sheep. Vet. Parasitol., 142(1-2): 1-15.

4. Gasser, R.B., Bott, N.J., Chilton, N.B., Hunt, P. and Beveridge, I. (2008) Toward practical, DNA-based diagnostic methods for parasitic nematodes of livestock-bionomic and biotechnological implications. Biotechnol. Adv., 26(4): 325-334.

5. Sangvaranond, A. and Lampa, N. (2005) Haemonchosis and helminth infections of meat goats in Saraburi Province. $J$. Kasetsart Vet., 15(1): 1-11.

6. Mangkit, B., Thaenkham, U., Adisakwattana, P., Watthanakulpanich, D., Jantasuriyarat, C. and Komalamisra, C. (2014) Molecular characterization of Haemonchus contortus (Nematoda: Trichostrongylidae) from small ruminants in Thailand based on the second internal transcribed spacer of ribosomal DNA. Kasetsart J. (Nat. Sci.), 48(5): 740-758.

7. Laosutthipong, C. and Eardmusic, S. (2017) Genetic characterization of Haemonchus contortus from slaughtered goats in Cha-am District, Phetchaburi Province, Thailand. Songklanakarin J. Sci. Technol., 41(1): 81-88.

8. Ghadirian, E. and Arfaa, F. (1973) First report of human infection with Haemonchus contortus, Ostertagia ostertagi, and Marshallagia marshalli (family Trichostrongylidae) in Iran. J Parasitol., 59(6): 1144-1145.

9. Roberts, L. and Janovy, J. Jr. (2000) Foundations of Parasitology. $6^{\text {th }}$ ed. Mc Graw Hill, New York.

10. Koehler, A.V., Bradbury, R.S., Stevens, M.A., Haydon, S.R., Jex, A.R. and Gasser, R.B. (2013) Genetic characterization of selected parasites from people with histories of gastrointestinal disorders using a mutation scanning-coupled approach. Electrophoresis, 34(12): 1720-1728.

11. Hussain, T., Periasamy, K., Nadeem, A., Babar, M.E., Pichler, R. and Diallo, A. (2014) Sympatric species distribution, genetic diversity and population structure of Haemonchus isolates from domestic ruminants in Pakistan. Vet. Parasitol., 206(3-4): 188-199.

12. Chaudhry, U., Redman, E.M., Raman, M. and Gilleard, J.S. (2015) Genetic evidence for the spread of a benzimidazole resistance mutation across Southern India from a single origin in the parasitic nematode Haemonchus contortus. Int. J. Parasitol., 45(11): 721-728.

13. Chaudhry, U., Redman, E.M., Abbas, M., Muthusamy, R., 
Ashraf, K. and Gilleard, J.S. (2015) Genetic evidence for hybridization between Haemonchus contortus and Haemonchus placei in natural field populations and its implications for interspecies transmission of anthelmintic resistance. Int. J. Parasitol., 45(2-3): 149-159.

14. Zhang, Z., Gasser, R.B., Yang, X., Yin, F., Zhao, G., Bao, M., Pan, B., Huang, W., Wang, C., Zou, F., Zhou, Y., Zhao, J., Fang, R. and Hu, M. (2016) Two benzimidazole resistance-associated SNPs in the isotype-1 beta-tubulin gene predominate in Haemonchus contortus populations from eight regions in China. Int. J. Parasitol. Drugs. Drug Resist., 6(3): 199-206.

15. Lambert, S.M., Nishi, S.M., Mendonca, L.R., da Silva Souza, B.M.P., da Silva Juliao, F., da Silva Gusmao, P. and de Almeida, M.A.O. (2017) Genotypic profile of benzimidazole resistance associated with SNP F167Y and F200Y beta-tubulin gene in Brazilian populations of Haemonchus contortus of goats. Vet. Parasitol. Reg. Stud. Reports, 8: 28-34.

16. Atanasio-Nhacumbe, A., Lambert, S.M., da Silva Souza, B.M.P. and Ayres, M.C.C. (2019) Molecular detection of benzimidazole resistance levels associated with F167Y and F200Y polymorphisms in Haemonchus contortus of goats from Mozambique. Parasitol. Res., 118(1): 245-253.

17. Shen, D.D., Peng, Z.W., Hu, M., Zhang, Z.Z., Hou, Z.J. and Liu, Z.S. (2019) A detection of benzimidazole resistance-associated SNPs in the isotype-1 beta-tubulin gene in Haemonchus contortus from wild blue sheep (Pseudois nayaur) sympatric with sheep in Helan Mountains, China. BMC. Vet. Res., 15(1): 89.

18. Arsenopoulos, K., Minoudi, S., Symeonidou, I., Triantafyllidis, A., Katsafadou, A.I., Lianou, D.T., Fthenakis, G.C. and Papadopoulos, E. (2020) Frequency of resistance to benzimidazoles of Haemonchus contortus Helminths from dairy sheep, goats, cattle and buffaloes in Greece. Pathogens, 9(5): 347.

19. Baltrusis, P., Komaromyova, M., Varady, M., von SamsonHimmelstjerna, G. and Hoglund, J. (2020) Assessment of the F200Y mutation frequency in the beta-tubulin gene of Haemonchus contortus following the exposure to a discriminating concentration of thiabendazole in the egg hatch test. Exp. Parasitol., 217: 107957.

20. Favero, F.C., Dos Santos, L.B., Araujo, F.R., Ramunke, S., Krucken, J., von Samson-Himmelstjerna, G. and Borges, F.A. (2020) Haemonchus spp. in beef cattle in Brazil: Species composition and frequency of benzimidazole resistance alleles. Prev. Vet. Med., 185: 105162.

21. Mohammedsalih, K.M., Krucken, J., Khalafalla, A., Bashar, A., Juma, F.R., Abakar, A., Abdalmalaik, A.A.H., Coles, G. and von Samson-Himmelstjerna, G. (2020) New codon 198 beta-tubulin polymorphisms in highly benzimidazole resistant Haemonchus contortus from goats in three different states in Sudan. Parasit. Vectors, 13(1): 114.

22. Kwa, M.S., Veenstra, J.G. and Roos, M.H. (1994) Benzimidazole resistance in Haemonchus contortus is correlated with a conserved mutation at amino acid 200 in beta-tubulin isotype 1. Mol. Biochem. Parasitol., 63(2): 299-303.

23. Silvestre, A. and Cabaret, J. (2002) Mutation in position
167 of isotype 1 beta-tubulin gene of trichostrongylid nematodes: Role in benzimidazole resistance. Mol. Biochem. Parasitol., 120(2): 297-300.

24. Ghisi, M., Kaminsky, R. and Maser, P. (2007) Phenotyping and genotyping of Haemonchus contortus isolates reveals a new putative candidate mutation for benzimidazole resistance in nematodes. Vet. Parasitol., 144(3-4): 313-320.

25. MAFF. (1971) Manual of Veterinary Parasitological Techniques. Her Majesty Stationary Office, London.

26. Jacquiet, P., Cabaret, J., Cheikh, D. and Thiam, E. (1997) Identification of Haemonchus species in domestic ruminants based on morphometrics of spicules. Parasitol. Res., 83(1): 82-86.

27. Silvestre, A. and Humbert, J.F. (2000) A molecular tool for species identification and benzimidazole resistance diagnosis in larval communities of small ruminant parasites. Exp. Parasitol., 95(4): 271-276.

28. Snedecor, G.W. and Cocharn, W.G. (1994) Statistical Methods. $8^{\text {th }}$ ed. Iowa University Press, Iowa, United States.

29. Arafa, W.M., Holman, P.J. and Craig, T.M. (2017) Genotypic and phenotypic evaluation for benzimidazole resistance or susceptibility in Haemonchus contortus isolates. Parasitol. Res., 116(2): 797-807.

30. Chagas, A.M., Sampaio, F.D. Jr., Pacheco, A., da Cunha, A.B., Cruz Jdos, S., Scofield, A. and GoesCavalcante, G. (2016) F200Y polymorphism of the beta-tubulin isotype 1 gene in Haemonchus contortus and sheep flock management practices related to anthelmintic resistance in Eastern Amazon. Vet. Parasitol., 226: 104-108.

31. Nagy, G., Csivincsik, A., Zsolnai, A. and Sugar, L. (2016) Benzimidazole resistance in Haemonchus contortus recovered from farmed red deer. Parasitol. Res., 115(9): 3643-3647.

32. Niciura, S.C., Verissimo, C.J., Gromboni, J.G., Rocha, M.I., de Mello, S.S., Barbosa, C.M., Chiebao, D.P., Cardoso, D., Silva, G.S., Otsuk, I.P., Pereira, J.R., Ambrosio, L.A., Nardon, R.F., Ueno, T.E. and Molento, M.B. (2012) F200Y polymorphism in the beta-tubulin gene in field isolates of Haemonchus contortus and risk factors of sheep flock management practices related to anthelmintic resistance. Vet. Parasitol., 190(3-4): 608-612.

33. Garg, R. and Yadav, C.L. (2009) Genotyping of benzimidazole susceptible and resistant alleles in different populations of Haemonchus contortus from Himalayan and sub-Himalayan regions of North-West India. Trop. Anim. Health Prod., 41(7): 1127-1131.

34. Tiwari, J., Kumar, S., Kolte, A.P., Swarnkar, C.P., Singh, D. and Pathak, K.M. (2006) Detection of benzimidazole resistance in Haemonchus contortus using RFLP-PCR technique. Vet. Parasitol., 138(3-4): 301-317.

35. Chandra, S., Prasad, A., Sankar, M., Yadav, N. and Dalal, S. (2014) Molecular diagnosis of benzimidazole resistance in Haemonchus contortus in sheep from different geographic regions of North India. Vet. World., 7(5): 337-341.

36. Nunes, R.L., dos Santos, L.L., Bastianetto, E., de Oliveira, D.A. and Brasil, B.S. (2013) Frequency of benzimidazole resistance in Haemonchus contortus populations isolated from buffalo, goat and sheep herds. Rev. Bras. Parasitol. Vet., 22(4): 548-553. 